Current Issues in Middle Level Education

Volume $25 \mid$ Issue 2

Article 7

2020

\title{
Teaching Candidates to Assess Student Learning: A COVID Collaboration with Arts and Sciences Faculty
}

Nancy B. Ruppert

UNC-Asheville, nruppert@unca.edu

Jessica Pisano

UNC-Asheville, jpisano@unca.edu

Follow this and additional works at: https://digitalcommons.georgiasouthern.edu/cimle

Part of the Curriculum and Instruction Commons, Junior High, Intermediate, Middle School Education and Teaching Commons, and the Secondary Education Commons

\section{Recommended Citation}

Ruppert, Nancy B. and Pisano, Jessica (2020) "Teaching Candidates to Assess Student Learning: A COVID Collaboration with Arts and Sciences Faculty," Current Issues in Middle Level Education: Vol. 25 : Iss. 2 , Article 7.

DOI: $10.20429 /$ cimle.2021.250207

Available at: https://digitalcommons.georgiasouthern.edu/cimle/vol25/iss2/7

This best practices is brought to you for free and open access by the Journals at Digital Commons@Georgia Southern. It has been accepted for inclusion in Current Issues in Middle Level Education by an authorized administrator of Digital Commons@Georgia Southern. For more information, please contact digitalcommons@georgiasouthern.edu. 


\title{
Teaching Candidates to Assess Student Learning: A COVID Collaboration with Arts and Sciences Faculty
}

\author{
Nancy B. Ruppert \\ Jessica Pisano \\ University of North Carolina, Asheville
}

\begin{abstract}
In the fall of 2020, due to COVID, our pre-service teachers did not have access to student work samples early in the semester. In order to learn how to assess student learning I reached out to an Arts and Sciences faculty who teaches a freshman course. The Arts and Sciences faculty was a former middle school teacher who was scheduled to talk about the teaching of writing in our methods class. We decided to add using work samples from her current students to provide an assessment experience. This exercise allowed pre-service teachers to create a one-point rubric, analyze student work, give feedback, examine patterns of learning for the whole class, as well as give suggestions for each student based on their work. The practice prepared them for their own fall teaching assignment, and all were able to analyze their students' works successfully.
\end{abstract}

\section{Background}

AMLE (2010; updated in 2021) describes leadership in exemplary middle schools as collaborative: "Leaders demonstrate courage and collaboration." Under the category of Curriculum, Instruction, and Assessment, we are directed that successful middle schools use "Varied and ongoing assessments [to] advance learning as well as measure it." During the 2020 Pandemic, we found our partner relationships with our Arts and Sciences faculty extremely helpful as we struggled to provide authentic experiences while preparing our candidates to assess student learning.

For language arts candidates, I (Nancy) turned to our English faculty liaison. Together we decided to help our candidates consider how to assess a formative instrument using item analysis (University of Washington, 2020). We received approval from the Institutional Review Board (IRB) to seek volunteers who would allow our candidates access to their first draft assignment based on writing a memoir. We used this process at the beginning of the semester so that when candidates taught their lessons towards the end of the semester, they were prepared to assess student learning.

\section{LANG 120, One of Our Liberal Arts Core Courses}

The English faculty liaison is a former middle and high school English teacher, currently a lecturer and Writing Program Coordinator in the English department. This fall she taught a service-learning designated course, LANG 120 (Academic Writing and Critical Inquiry: Academic Narratives \& Writing Communities), in which first-year students applied the skills they're learning as online writing tutors for local high school students. As part of their preparation for tutoring, students wrote a memoir detailing and reflecting on an experience that 
changed the way they think about reading, writing, education, or communication. This reflection, in conjunction with readings on best practices in the teaching and tutoring of writing, prompted these first-year college students to develop a philosophy that undergirds their work as tutors.

Seven of these first-year students' memoirs provided our pre-service teachers with an opportunity to learn how to assess writing. Working together, we shared these drafts with preservice teachers who then responded using a one-point rubric (Fluckiger, 2010). This collaboration between the English and Education departments not only gave first-year students valuable feedback and an experience that reminds them of how it feels to be tutored, but also provided an opportunity for pre-service teachers to practice analyzing student work using item analysis (University of Washington, 2020).

\section{The Process}

\section{Step 1. Using Item-Analysis to Assess Student Learning}

As an introduction to this collaboration, the English liaison led a three-day workshop with the pre-service teachers at the beginning of the semester. This workshop guided students to reflect on their own experiences receiving feedback, differentiate between grading and assessment as well as formative and summative assessments, and consider diverse strategies for responding to student writing.

We then introduced the memoir prompt. Using the first draft of the LANG 120 students, our candidates first aligned the expectation into a single-point rubric. Gonzalez (2015) shares the process for creating a rubric that starts with how each criterion "meets" the expectations.

This provided pre-service teachers an opportunity to practice designing a tool they could use to analyze each item separately. Additionally, we added a column for pre-service teachers to provide specific feedback for each student based on each item. The following is the single-point rubric they designed.

\begin{tabular}{|c|c|c|c|c|}
\hline & Feedback & $\begin{array}{l}\text { Below } \\
\text { Expectations }\end{array}$ & $\begin{array}{l}\text { Meets } \\
\text { Expectations }\end{array}$ & $\begin{array}{l}\text { Exceeds } \\
\text { Expectations }\end{array}$ \\
\hline $\begin{array}{l}\text { 3-4 pages, double- } \\
\text { spaced, and in MLA }\end{array}$ & & & & \\
\hline $\begin{array}{l}\text { essay-it should have a } \\
\text { main point, or thesis } \\
\text { that relates some } \\
\text { realization about how a } \\
\text { particular moment } \\
\text { changed the way you } \\
\text { view writing, reading, } \\
\text { communication, or } \\
\text { education. }\end{array}$ & & & & \\
\hline
\end{tabular}




\begin{tabular}{l|l|l|l|}
\hline a memoir, employing & & & \\
narration and \\
description as evidence \\
in support of your \\
thesis.
\end{tabular}

We then looked at the items to see how they aligned with academic language demands. According to Stanford Center for Assessment, Learning, and Equity (SCALE, 2018), pre-service candidates need to be able to create a written product to illustrate their ability to respond to text and address the following academic language demands: vocabulary, language function, discourse, and syntax. As the following table indicates, this assignment and rubric successfully addressed all of these elements.

\begin{tabular}{|l|l|l|l|}
\hline \multicolumn{1}{|c|}{\begin{tabular}{l|l|} 
3-4 pages, \\
double-spaced, and in \\
MLA
\end{tabular}} & $\begin{array}{l}\text { Language } \\
\text { Function }\end{array}$ & Discourse Syntax \\
\hline $\begin{array}{l}\text { essay-it should have a } \\
\text { main point, or thesis } \\
\text { that relates some } \\
\text { realization about how a } \\
\text { particular moment } \\
\text { changed the way you } \\
\text { view writing, reading, }\end{array}$ & & & \\
\hline
\end{tabular}




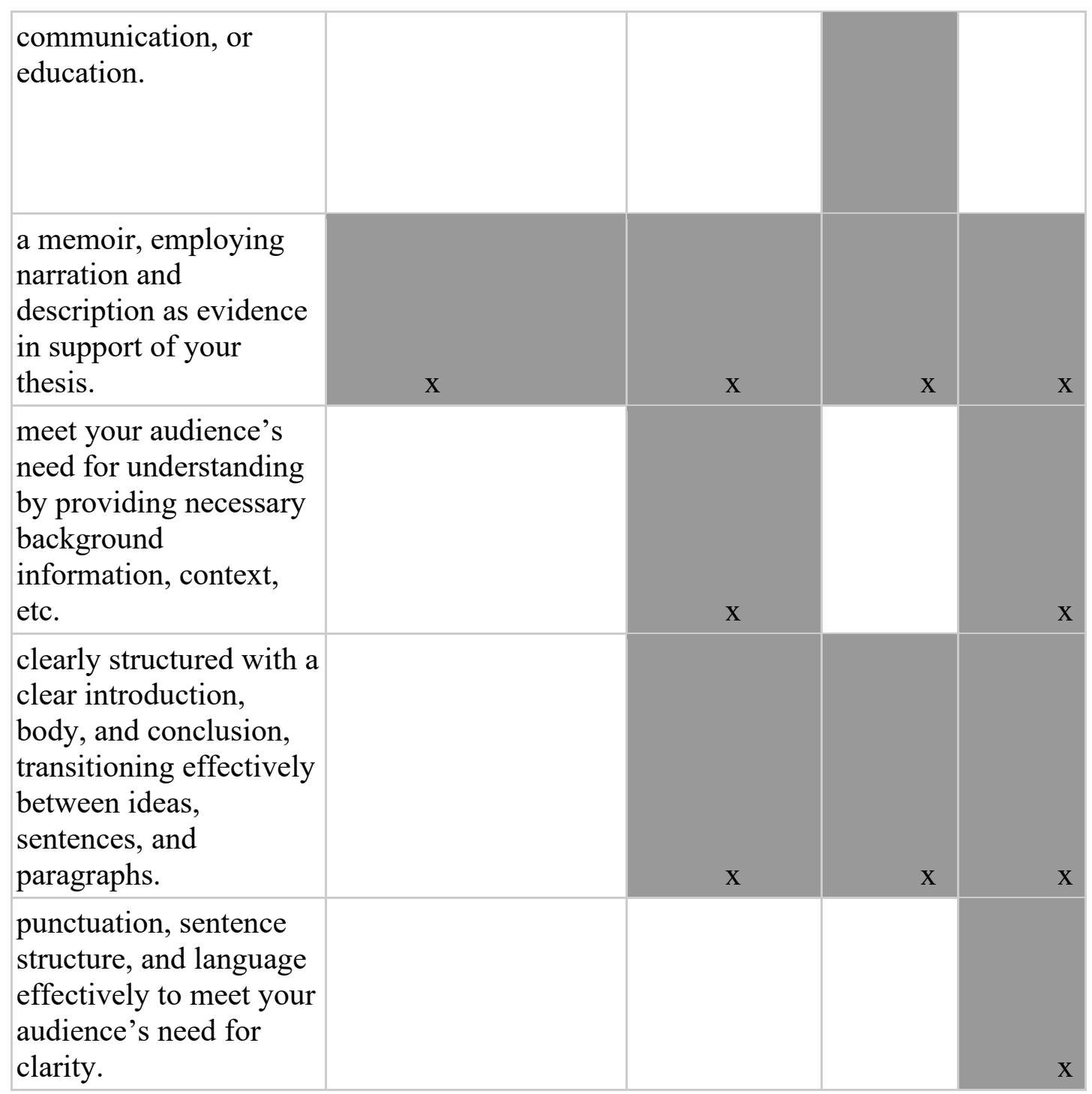

\section{Step II. Assessing Student Learning}

A group of seven first-year students, diverse in terms of gender, race, and academic preparation, volunteered their memoirs to be placed in a Google Drive folder. As a class we addressed each of the items, giving candidates the opportunity to describe two different criteria from two different samples. Each pre-service teacher explained their reasoning and the class was able to describe what "meets" criteria looked like for each item. From there each pre-service teacher scored one student's work individually. Pre-service teachers then shared their thinking with the group. This exercise helped licensure candidates conceptualize what good feedback looks like according to Wormeli (2018). The following is a response to one student's draft which we scored together for practice prior to creating individual assessments. 


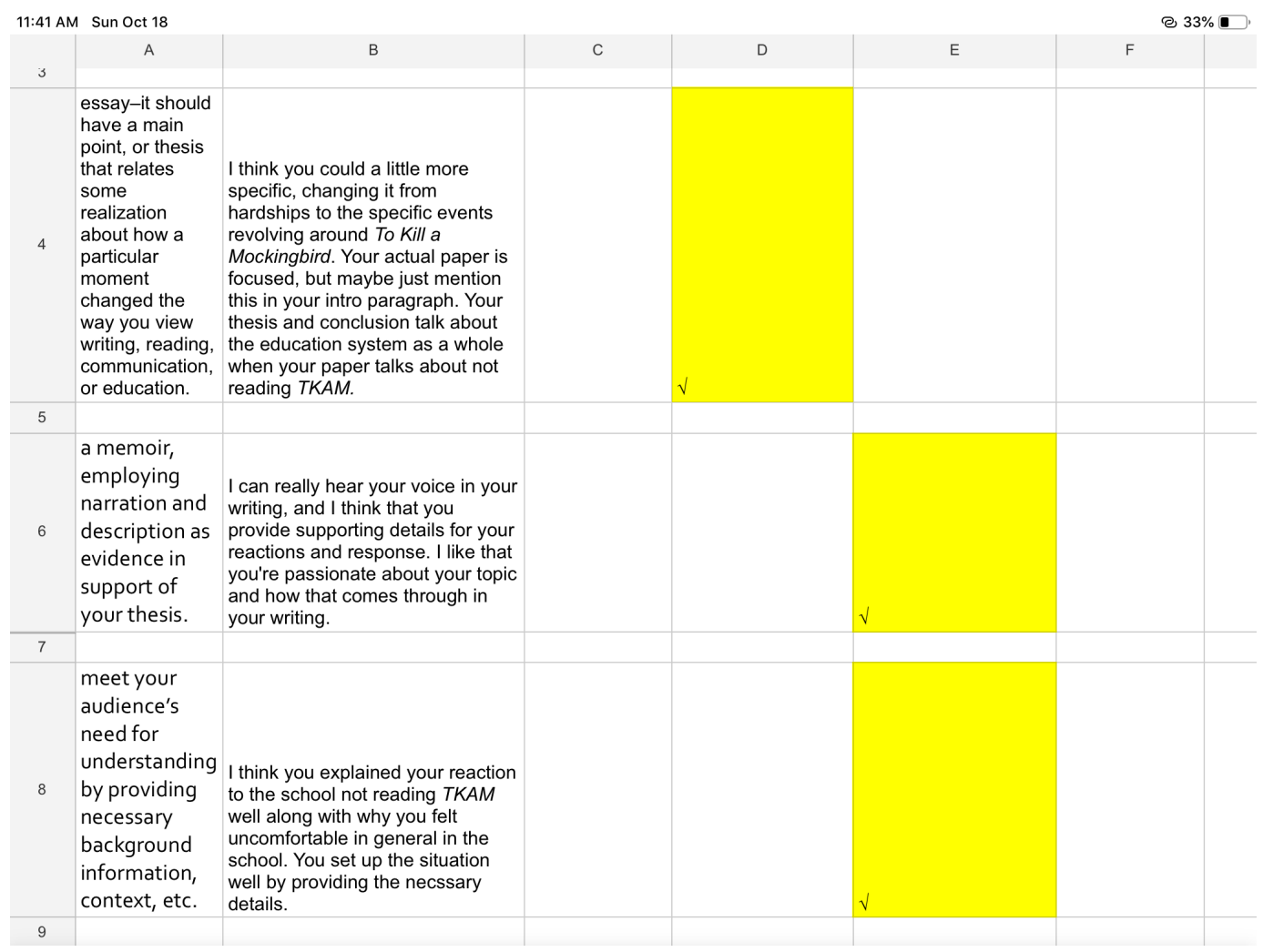

\section{Step III. Implementing an Item Analysis to Deepen the Knowledge of Students' Skills}

Once all of the students' memoirs had been "scored" we set up a spreadsheet with frequencies of below, met, or exceeded expectations. These scores allowed us to discuss strengths and weaknesses of the group as a whole. We analyzed overall performance on each item and brainstormed suggestions for developing future instruction to meet these specific writing needs. The following is our frequency table.

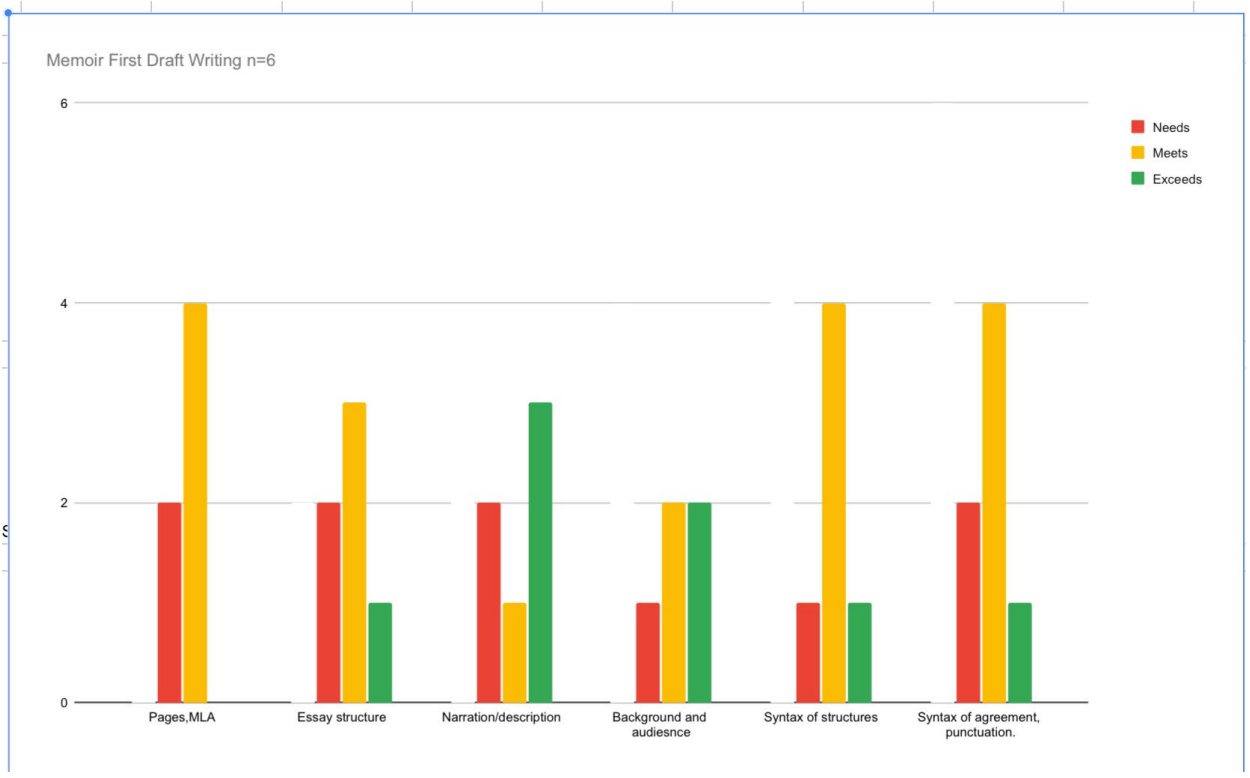


We determined collectively that findings suggest that most of the students either met or exceeded the expectations for each criterion. We then looked at the individual students' scores, observing patterns that emerged as their performance related to the whole class. Additionally, we looked at each student to consider what individual strategies we might implement to assist them in their writing. The following is our analysis of how each student performed on the individual criteria.

\begin{tabular}{|c|c|c|c|}
\hline Criteria & $\begin{array}{l}\text { Below } \\
\text { Expectation }\end{array}$ & $\begin{array}{l}\text { Meets } \\
\text { Expectation }\end{array}$ & $\begin{array}{l}\text { Exceeds } \\
\text { Expectation }\end{array}$ \\
\hline $\begin{array}{l}\text { 3-4 pages, double- } \\
\text { spaced, and in MLA }\end{array}$ & $\mathrm{S} 1, \mathrm{~S} 2$ & 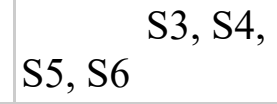 & \\
\hline $\begin{array}{l}\text { essay-it should have } \\
\text { a main point, or thesis that } \\
\text { relates some realization } \\
\text { about how a particular } \\
\text { moment changed the way } \\
\text { you view writing, reading, } \\
\text { communication, or } \\
\text { education. }\end{array}$ & $\mathrm{S} 2, \mathrm{~S} 5$ & S1, S3, & S4 \\
\hline $\begin{array}{l}\text { a memoir, } \\
\text { employing narration and } \\
\text { description as evidence in } \\
\text { support of your thesis. }\end{array}$ & $\mathrm{S} 1, \mathrm{~S} 2$ & S5 & S3, S4, \\
\hline \begin{tabular}{l}
\multicolumn{1}{c}{ meet your } \\
audience's need for \\
understanding by providing \\
necessary background \\
information, context, etc.
\end{tabular} & S2 & S1, S5 & S3, S4, \\
\hline $\begin{array}{l}\quad \text { clearly structured } \\
\text { with a clear introduction, } \\
\text { body, and conclusion, } \\
\text { transitioning effectively } \\
\text { between ideas, sentences, } \\
\text { and paragraphs. }\end{array}$ & S2 & 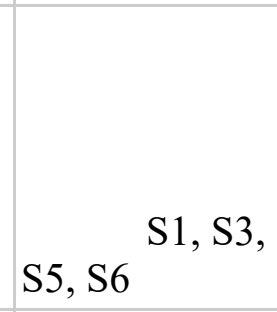 & S4 \\
\hline
\end{tabular}




\begin{tabular}{l|l|l|l|}
\hline \multicolumn{1}{|c|}{ punctuation, } \\
$\begin{array}{l}\text { sentence structure, and } \\
\text { language effectively to meet } \\
\begin{array}{l}\text { your audience's need for } \\
\text { clarity. }\end{array}\end{array}$ & S2, S5 & S4, S6 S1, S3, & S4 \\
\hline
\end{tabular}

This process allowed pre-service teachers to learn a set of strategies, practice with their peers, and share their thoughts and ideas with one another.

\section{Strategies We Used}

One tool we use to assess student learning was to create a rubric so that students would know what was expected of them (Wiggins \& McTigue, 1998). For this exercise we used a 'single-point rubric' (Fluckiger, 2010). The rubric consists of a description of the criteria along with what is below standard and what is above standard. We set up an Excel spreadsheet to capture our thinking. As a class we analyzed the rubric using the expectations of planning for academic language demands (SCALE, 2018). For each of the six criteria, we discussed what would indicate meets expectations. From there we discussed what below and above expectations would look like.

A second strategy we used relates to giving students feedback. Wiggins (2010) provides examples of helpful advice and shares, "Helpful feedback is goal-referenced; tangible and transparent; actionable; user-friendly (specific and personalized); timely; ongoing; and consistent" (p. 11). As a class we examined two of the seven students collectively. For each item, we identified positive, constructive, and specific advice on how to improve the draft. Each candidate then analyzed a student draft individually and shared their thinking with one another prior to compiling all of our evidence. The collection of student scores provided opportunities for pre-service teachers to share their positive, constructive feedback as well as suggestions for using the feedback and to hear what others were thinking.

A third strategy we used is called item analysis (University of Washington, 2020). Once all participants' memoirs had been scored, we created a chart to analyze each item of the data as a "whole class." (In this case, our whole class consisted of six of the seven students.) We used our findings to identify whole class patterns as well as how we might support individual students.

After completing this experience, pre-service teachers used this process to analyze their own teaching with a whole class. Their products illustrate comprehension of how to use onepoint rubrics and item analysis to better understand and impact students' learning.

\section{Conclusions}

Working collaboratively with the English faculty in this capacity was new. We both share a passion for teaching. In the past the English liaison has shared her passion by teaching licensure classes within the English department and facilitating single-day workshops as a part of the methodology course, but adding actual student work gave our pre-service teachers authentic exposure to how first-year students write and the challenges they have.

At the end of the semester, after this collaboration with first-year writing students, our pre-service teachers had to implement a three-day virtual teaching experience. Each of them has had to analyze their students' performance. All four pre-service teachers are using the item analysis and one-point rubric successfully. When it came time to analyze their own teaching, 
they were able to participate in discourse related to item analysis, giving feedback, and associating research with their reflections.

Using first-year student work to model how to give feedback was a great tool. While using middle school tools would have been better, we were able to use student writing to make the case for how to assess student writing. Because the English faculty member used a rubric, we were also able to analyze the student work in light of the SCALE (2018) definition of academic language demands including discourse, vocabulary, evidence of a language function, and syntax. These are language demands expected for middle school students.

\section{References}

Fluckiger, J. (2010). Single Point Rubric: A tool for responsible student self-assessment. Teacher Education Faculty Publications. https://digitalcommons.unomaha.edu/tedfacpub/5

Gonzalez, J. (2015). Meet the single point rubric. Cult of Pedagogy [website] Retrieved from: https://www.cultofpedagogy.com/single-point-rubric/

Harrison, L. M., \& Bishop, P. A. (2021). The successful middle school: This we believe. Association for Middle Level Education.

National Middle School Association. (2010). This we believe: Keys to educating young adolescents. Author.

SCALE (2018). Stanford Center for Assessment, Learning and Equity. [website]. Retrieved from https://scale.stanford.edu/teaching/consortium

University of Washington (2020). Understanding item analysis. Office of Educational Assessment. Retrieved from https://www.washington.edu/assessment/scanningscoring/scoring/reports/itemanalysis/\#: :text=Understanding\%20Item $\% 20$ Analyses $\% 201 \% 20$ Item $\% 20$ Statistics. $\% 20$ Item $\% 20$ statistics,A $\% 20$ Caution $\% 20 \mathrm{in} \% 20$ Interpreting\%20Item $\% 20$ Analysis $\% 20$ Result s. $\% 20$

Wiggins, G. (2012). Seven keys to effective feedback. Educational Leadership, 70(1), 10-16.

Wiggins, G. \& McTigue, J. (2005). Understanding by Design. Pearson

Wormeli, R. (2018). Fair isn't always equal. Westerville, OH: Stenhouse 